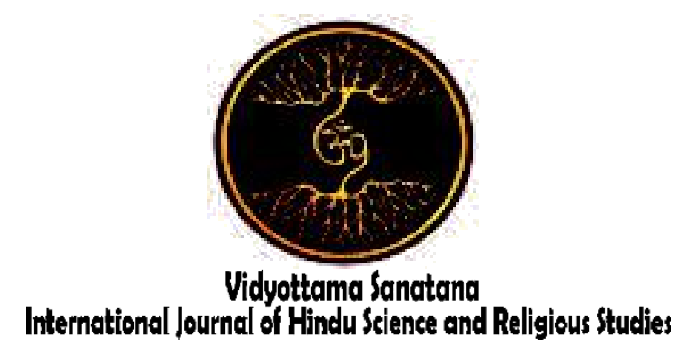

Vol. 2 No. 1 May 2018

\title{
Organizational Harmony in Hindu Higher Educatiob Institution based on Tri Hita Karana Culture
}

\author{
By: \\ I Gede Sedana Suci ${ }^{1}$, Ahmad Sonhadji K.H. ${ }^{2}$, Ali Imron ${ }^{2}$, Imron Arifin ${ }^{2}$ \\ ${ }^{1}$ Post Graduate Program, State University of Malang, Malang City, East Java, \\ ${ }^{2}$ State University of Malang, Malang City, East Java,Indonesia \\ E-mail: sucisedana@gmail.com
}

Received: January 11, 2018

Accepted: May 8, 2018

Published: May 31, 2018

\begin{abstract}
Universities as knowledge-based organizations need to have a conducive, adaptive and flexible structure and culture, in facing any changes. The ideals of becoming a professional organization can be realized, but it demands the organizational components involved directly in the process of forming human resources, ie employees and lecturers must have a harmonious relationship, it should be realized that the harmonization in the college organization is very important. It takes individual awareness, as well as their communal role within the organization to avoid disharmony. Therefore, a good culture is created within the organization. Hinduism teachings taught the concept of Tri Hita Karana or three causes of happiness, in which the achievement of harmonious relationships based of aspects of religious, sociological and ecological. In the implementation these three causes are integrated with each other and mutually influence the creation of harmony of organization goals will be more easily achieved.
\end{abstract} Keywords : Harmonization, Organization, Tri Hita Karana.

\section{INTRODUCTION}

University as an organization which prepares human resources faces dire challenges in reading the needs of the market which will be faced by its graduates in order to prepare its graduate to face the challenges of the era. These conditions require the components of a learning higher education institutions which directly involved with the preparation of human resources, namely the lecturers and staffs must have a harmonious relationship. Since the vital process of 
teaching and learning, research, and community services will only run smoothly when the involved components also work well together. Universities are a subsystem of the society, with their own culture (Suharsaputra,2015:46). The culture of the university including Hinduism-based university is inseparable from the culture adhered by its members, in this case Hinduism university is supported by its Hindu members.

$$
\text { Organizational objectives are }
$$
achieved when the three components of higher education occur harmonious relationships, it will increase lecturers and employees' performance in serving students or in performing their main tasks as part of the organization, therefore, the three components of the relationship are dynamic and changeable in pursuant to the situation and conditions. The reality is that lecturers, students and employees need and complete each other, in performing their respective duties and roles. However, sometimes problems unwittingly arose in the dynamic of the relationship between the lecturers with staffs and vice versa.

This is where the organizational culture plays as a reference for each member in performing their respective roles and improving performance. Rival, et al (2011) explained that the increase of organizational performance required a strong organizational culture, including values, norms and attitudes. Based on these facts it should be realized that the harmonization in the university organization is very important and necessary including in Hindu religious university. Without harmony the process of cooperation will not run properly, organizational culture will be meaningless and this affects the performance of the organization itself. To achieve this requires the awareness of individuals, and groups to avoid disharmony. Hindu religion clearly taught the concept of Tri Hita Karana, namely the creation of harmonious relationships both vertically and horizontally.

The importance of creating harmonious relationships based on Tri Hita Karna organizations culture in Hindu university. The organization culture of Hindu university in Bali is strongly influenced by the culture of Tri Hita Karana, in which there are the elements of Parhyangan, Pawongan and Palemahan (religious, sociological and ecological) (Winda, et.al, 2011). By cultivating this concept it is expected to prompt values that serve as guidance in building relationships and cooperation to realize the harmonization of the organization for the creation of a quality college and able to answer the challenges of the era amid increasingly fierce competition in the era of information and technology increasingly sophisticated and modern. Religious values and cultures are very potential to support the succession and implementation of the management of accountable educational institutions, Diana (2012).

The religious element in Tri Hita Karana describes how man is aware of the existence of God and influences his daily activities including in carrying out his religious activities. Schein (2004) explains that there are things that can not be explained related to ideology and religion. The sociological aspect that must be considered how each individual mutual respect, the balance between rights and obligations, 
therefore the management must be transparent because it will affect the participation of the manpower (Windia, et.al, 2011). Ecological element in Bali is the physical aspect of the surrounding environment that is closely related to the organization's layout and building that is adapted to the religious beliefs and the surrounding culture (Winata, et.al, 2015)

There is a close relationship between the interaction of organizational culture with community culture, Sagiv and Scwartz (2007). This opinion reinforces that the organizational culture is a subsystem of the culture of society. The Tri Hita Karana cosmology value adopted by Balinese society will indirectly internalize into organizational culture. Tri Hita Karana comes from the word Tri which means three, Hita means happy and Karana which means cause, therefore, it can be interpreted as the three causes of harmony. The three causes are the religious, sociological and ecological aspects, termed (Parhayangan, Pawongan, and Palemahan respectively) intertwined with each other. This means that there must be a harmony in the relationship of men with God, men with fellow man, and men with its environment. Therefore, in a broad sense it can be said that Tri Hita Karana can be interpreted as the concept of harmony and togetherness (Windia, et.al, 2011)

Therefore, it is important to examine the harmonization process in higher education organizations based on Tri Hita Karana culture in improving organizational performance and organizational cultures formed by the interaction among members of the organization.

\section{METHODS}

The method used in this research is descriptive qualitative through interview study, observation, and documentation. Descriptive data used in the form of interviews and results of behavior observation. The research design used was case study (Yin 1998). The case study design is one form of design that is used to develop theories raised from several similar research backgrounds, so that a theory can be transferred to a wider and more generalized situation (Ulfatin 2015). There are 5 Hindu universities in Bali Province with two state universities and 3 private universities, The sampling techniques used in this study is purposive sampling. The sample used is the Denpasar Hindu Dharma State Institute (IHDN Denpasar). This study is a qualitative study which leads to an explanation to understand social phenomena from the informant's perspective. In accordance with the nature of qualitative research, this study explains and describes the events, activities, beliefs, attitudes, social and thinking of the good people individually and in groups. This description is used to find the principle that leads to the conclusion (Sukmadinata, 2006).

The data were collected using observation technique, in-depth interview, documentation study and active participation at IHDN Denpasar. Qualitative data analysis is done interactively and carried out continuously at every stage of research, until complete and saturated. Data analysis techniques used in the study were (1) content analysis techniques (2) domain analysis techniques (3) taxonomic analysis techniques (4) component analysis techniques (4) theme analysis techniques, (5) induction analysis 
techniques (Bungin, 2007, Bogdan and Biklen, 1998). While the process of data analysis following the cycle described by Miles and Huberman (1994) as follows:

Figure 1.1 Data Analysis Cycle

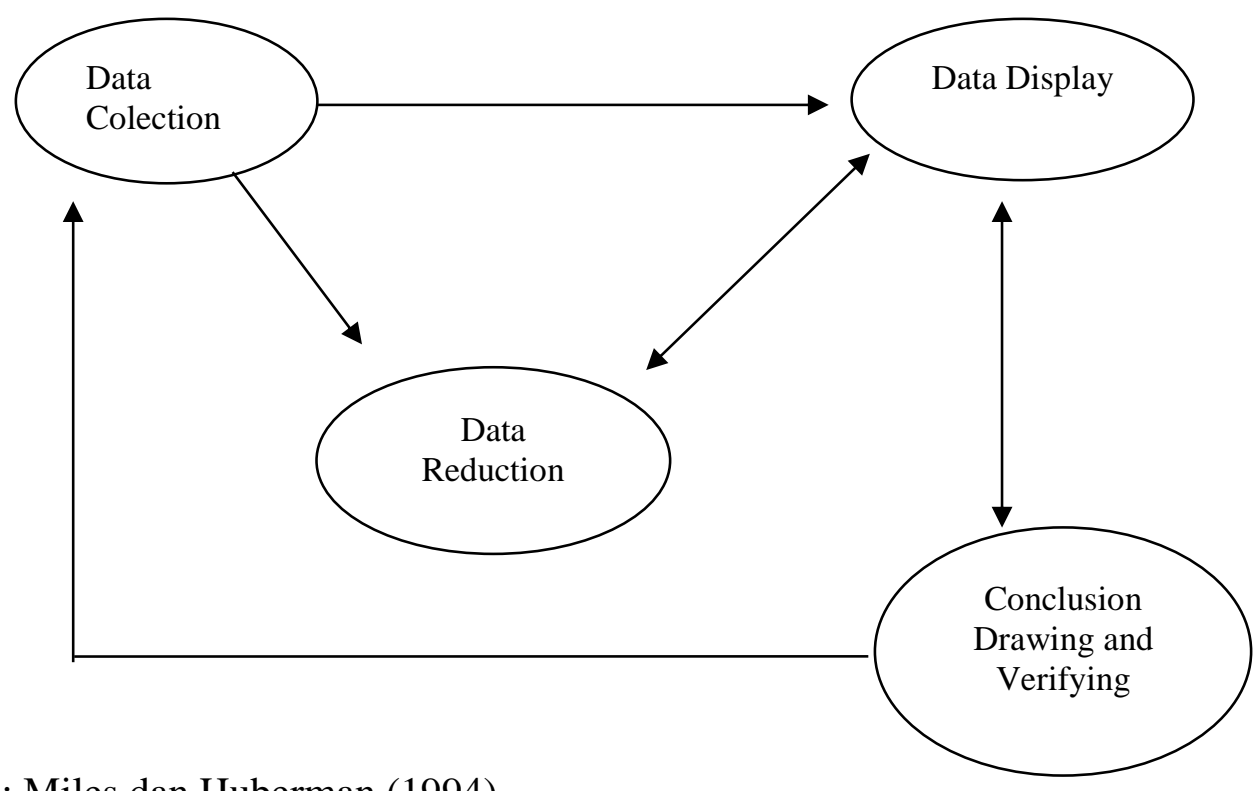

Source: Miles dan Huberman (1994)

\section{RESULTS AND DISCUSSION}

\subsection{Results}

The findings data were obtained from interviews with informants consisting of rectors as policymakers at the level of Hindu institutions, the Dean as policyholder at the faculty level, the Head of Department as executor in the Department, Lecturers and Students as the executor of the policy as part of the component in the Hindu university.

From the results of interview, observation and documentation, it can be expressed that the harmonization of Hindubased university organizations is based on Tri Hita Karana culture, formed from the foundations of values contained in the holy books of Hinduism, where Hindus must be harmonious in their relationship with God Almighty, with each other, and with the natural environment. The meaning to be taken from this concept is that the harmony that occurs in the organization that is both vertical and horizontal, known as parhayangan (religious), pawongan. (sociological), and palemahan (ecological) (Windia, et.al, 2011; Winata.et.al, 2015; Gunawan, 2011).

Lecturers, staff and students are the three components involved directly in the university or often referred to as the academic community. These components can create an effective, efficient and high-quality organization, through the cooperation of the academic community. The field of cooperation is implemented into actions that lead to the development of religious, sociological and ecological values, as a foundation in maintaining harmony and becoming a culture in the Hindu university organization. 
Based on research conducted, the socialization or internalization of Tri Hita Karana cultural values into the Hindu unviersity organization, carried out integratedly by each of these aspects. The harmony built with the cultural values of Tri Hita Karana and supported by other concepts in its implementation can be explained as follows.

First, to maintain harmony with God Almighty (religious) aspect, is built through the growth of individual or personal awareness of each academic community member with four paths known as Catur Marga Yoga. To get closer to God Almighty a medium of worship such as the holy place is required. Through this medium with all the activities in it harmony is built. Such as praying at the time of prayer or full moon in the Pura in campus, or Puja Saraswati during the Sarasvati day celebrated as the day of the revelation of science.

As an organization engaged in education, Saraswati holy day is a major religious day, as a celebration of the revelation of science to mankind. Furthermore, in each room there is a Pelangkiran (symbol God's throne) where the purpose of placing the symbol in the room is aimed at placing God closer to man at all time, and despite their work man should always keep in mind The Creator, even though people may not have time to carry out worship in the holy place at least still be done inside the room. Praying before starting any activities for employees or starting the class for students and lecturers. All these things are done with a sincere sense of devotion. Appreciate all and understand that all living beings are part of God (Atman Brahman Aikyam).
Second, maintaining harmony with fellow human beings (sociological aspect), namely the harmony with among the academic community, the real implementation of Catur Marga in the interaction as; exemplary model by the leader of each unit for his subordinates based on the concept of Tri Kaya Parisuda (proper and correct thinking, noble and correct speech, noble and correct action) these three things are done in an integrated manner. Harmony also promoted by implementing the concept of menyame braya (brotherhood). And Tat Twam Asi (I am you, as you are I). these concepts act as the foundation in implementing harmony with fellow stakeholders of the university.

Third, maintaining harmony with the environment (ecological), the term environment here refers to both the natural environment and social environment, social environment is the components outside the organization or university such as the surrounding community, which can support the university in the form of a safe and pleasant environment. Therefore, it is important that the organization maintain communication and help each other and work with the surrounding community. This can be done by maintaining and preserving the environment such as maintaining the parks, planting rare trees, or trees used in religious ceremonies. Meanwhile, inside the campus itself this can be done by planting ornamental flowers that can also be used as a means of praying, so that the environment of the academic community to be beautiful and pleasant, thus everybody will feel comfortable in performing their respective duties. 
Harmonization of universities based on Local Culture of Bali based on the concept of Tri Hita Karana is performed by upholding the following principles: 1) Upholding the spirit of Brotherhood (Manyama Braya), 2). Mutual respect (Saling Asah), 3). Love each other (Saling Asih), 4). Mutual Care (Saling
Asuh) and 5). Togetherness through thick and thin (Paras-Paros Sarpanaya).

The interactions of the members of the academic community in a Hindu university based on Tri Hita Karana to achieve harmony, can be displayed as follows:

\section{Table 1.1. Tri Hita Karana Culture Values in Organization Harmonization}

\begin{tabular}{|c|c|c|}
\hline No & $\begin{array}{c}\text { Tri Hita Karana } \\
\text { Culture Values }\end{array}$ & Organization Harmonization Implementation \\
\hline 1 & $\begin{array}{l}\text { Harmonious } \\
\text { Relationship with } \\
\text { God } \\
\text { Religious Aspect } \\
\text { (Parhayangan) }\end{array}$ & $\begin{array}{l}\text { Get closer with God through catur marga yoga } \\
\text { (Bhakti Marga yoga, Karma Marga yoga, Jnana } \\
\text { Marga yoga dan Raja Marga yoga). }\end{array}$ \\
\hline 2 & $\begin{array}{l}\text { Harmonious } \\
\text { Relationship with } \\
\text { Fellow Human } \\
\text { Sociological Aspect } \\
\text { (Pawongan) }\end{array}$ & $\begin{array}{l}\text { Using catur marga yoga as the main foundation } \\
\text { in harmonizing with God and supported by the } \\
\text { concepts of tri kaya parisudha, tat twam asi, and } \\
\text { menyama braya. }\end{array}$ \\
\hline 3 & $\begin{array}{l}\text { Harmonious } \\
\text { Relationship with the } \\
\text { environment } \\
\text { Ecological Aspect } \\
\text { (Palemahan) }\end{array}$ & $\begin{array}{l}\text { The harmony with God (Vertical) and fellow } \\
\text { human (horizontal) will run smoothly if there is } \\
\text { also harmony with social and natural } \\
\text { environment. This can be done by cooperating } \\
\text { with government agencies, arranging and } \\
\text { maintaining the environment, since the } \\
\text { environment gives positive contribution to man, } \\
\text { and also provide the sense of coolness and peace } \\
\text { when interacting with fellow man. }\end{array}$ \\
\hline
\end{tabular}

From the table above, we can describe that the organization based on Tri Hita Karana culture can be affected by the following domains. 


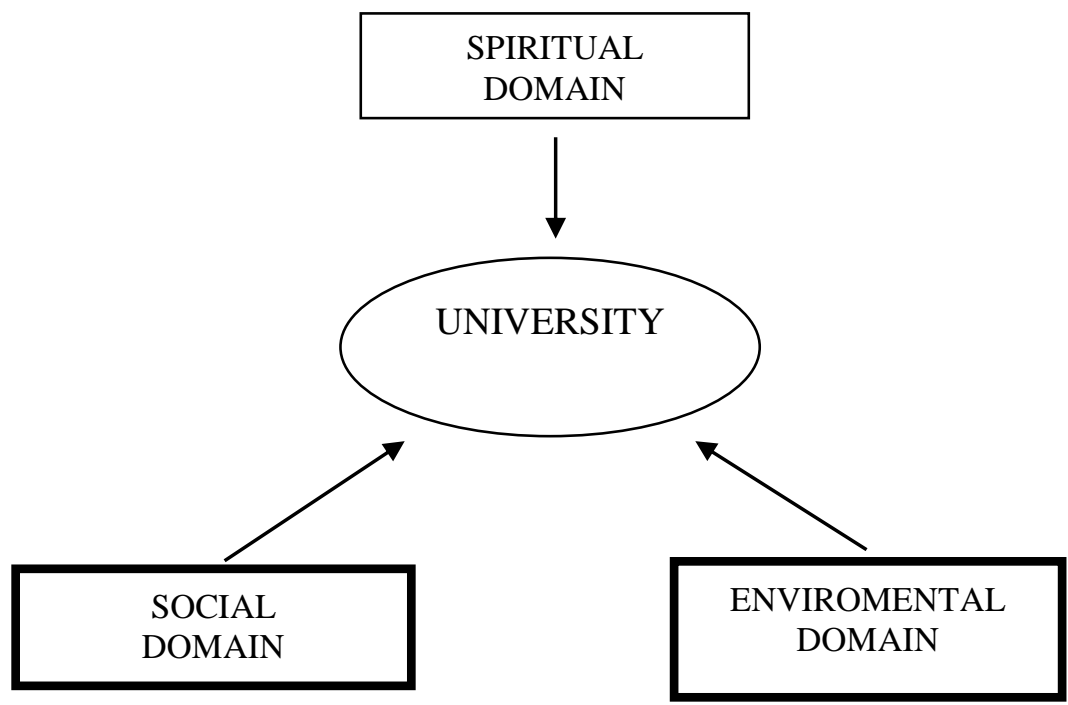

\subsection{Discussion}

Harmonization of Hindu university based on Tri Hita Karana in practice is to carry out the values contained in Hinduism and also supported by local wisdom. This value is the basis in establishing a harmonious relationship in Hindu university organization. This harmonious relationship have an impact on the components or members of the organizations involved in the university. The impact is to get a direct influence from each of these environments in both the religious, sociological and ecological environments.

These harmonious relations are interrelated and can not be separated from each other this is called the concept of Tri Hita Karana cosmology, this cosmology is implicated in the organization so entrenched and become the main ground in running the organization in order to create harmonization in Hindu university.

The components or aspects of Tri Kaya Parisudha such as the harmonious relationship with God of the religious aspect (parhyangan) will produce a spiritual environment, harmonious relationship with fellow human sociological aspects (pawongan) will produce a social environment and the last harmonious relationship with the environment will produce the natural environment. All three components of his environment are integrated and affected the other components, simply said, these environments give a direct vibration to each other.

Spiritual environment as a media of academic community within the organization to harmonize themselves with God through various ritual activities of religious ceremony is one way to get closer to self or harmonize to God by way of devotion. in Hinduism it is clear that there are four ways to get closer to God, namely: (1) bhakti marga yoga, (2) karma marga yoga (3) marga jnana yoga and the last is (4) raja yoga. with the success of running one or all of them well it will produce several benefits such as; (1) the tranquility of the soul, (2) the emergence of a sense of gratitude, (3) the human is small in front of its creator (4) the emergence of spiritual 
happiness. (5) realize that there are supernatural powers that govern the functions and motions present in this world.

This situations and conditions will affect the atmosphere of the work environment of the organization itself. With the theological awareness, the work orientation will not be separated from the consciousness or belief that it holds and give birth to a serving culture. In Hinduism theological concept it is clear that serving others is the same as serving God, with that concept the academic community of the organization will be service oriented in working. If this is done in a sustainable way it will give birth to this culture of service also in accordance with the concept of bhakti marga in Hindu religion which is way to get closer to God through bhakti (service to other), and the resulting culture is a culture of service.

In serving others it is necessary to have a good knowledge of the work one is doing so that one can be called a professional. To become a professional, it takes continuous training and good education. This describes that human resources that exist in an organization, will be useful if they continue to want to learn. In the Catur Marga concept it is also clearly stated that the next path to get closer to God is the jnana marga that is a way of getting closer or harmonious with God through the way of knowledge/learning. this means that when members of the organization truly adhere to the concept then the resulting culture is a culture of learning.

With the awakening of the awareness to serve with the knowledge it possesses the dedication, loyalty, and responsibility of human resources in the work will be total, in accordance with their basic functions and duties within the organization. situation and the condition if it can be considered and then a culture within the organization is born in this social environment of work culture. Namely the culture of resilience in working because it is based on the culture of serving, learning culture and this affect the results of professional work. And the last one in accordance with the concept of Catur Marga that is the way to get closer to God by way of discipline or Yoga Marga. If the members of the organization do not have any discipline, they will not work according to the SOP. Thus with discipline the members of the organization will work together and give birth to a culture of discipline. Therefore, it is clear that in the social environment the four cultures are: (1) working culture, (2) the culture of serving, (3) learning culture and (4) the culture of discipline or can we call those cultures with the term of the Four Culture or Catur Budaya. These four cultures or Catur Budaya can stem from spiritual domain affecting the environmental domain or vice versa. With the existence of this Four Culture within the social environment then the productivity of work members of the organization will be achieved the predetermined goals.

The condition of the social environment can work well if the natural environment is well ordered and sustainable, with green vegetation which will provide good oxygen for living creatures around it, fresh air will provide a comfortable situation in work in, hot weather will have an impact on the working environment, a little disagreement between members then the emotions will culminate, when people fight, they will forget the values of religion as well 
as the social values which hold the affected by the yadnya performed for the organization together.

plats, namely the Tumpek Uduh, a sacred Therefore, it is vital to maintain the sacrifice during Saniscara Wariga. Therefore, environment, because it also affect the social in its implementation all these aspects must and religious aspect. In social aspect it is complement each other.

Broadly the above explanation can be described as follows:

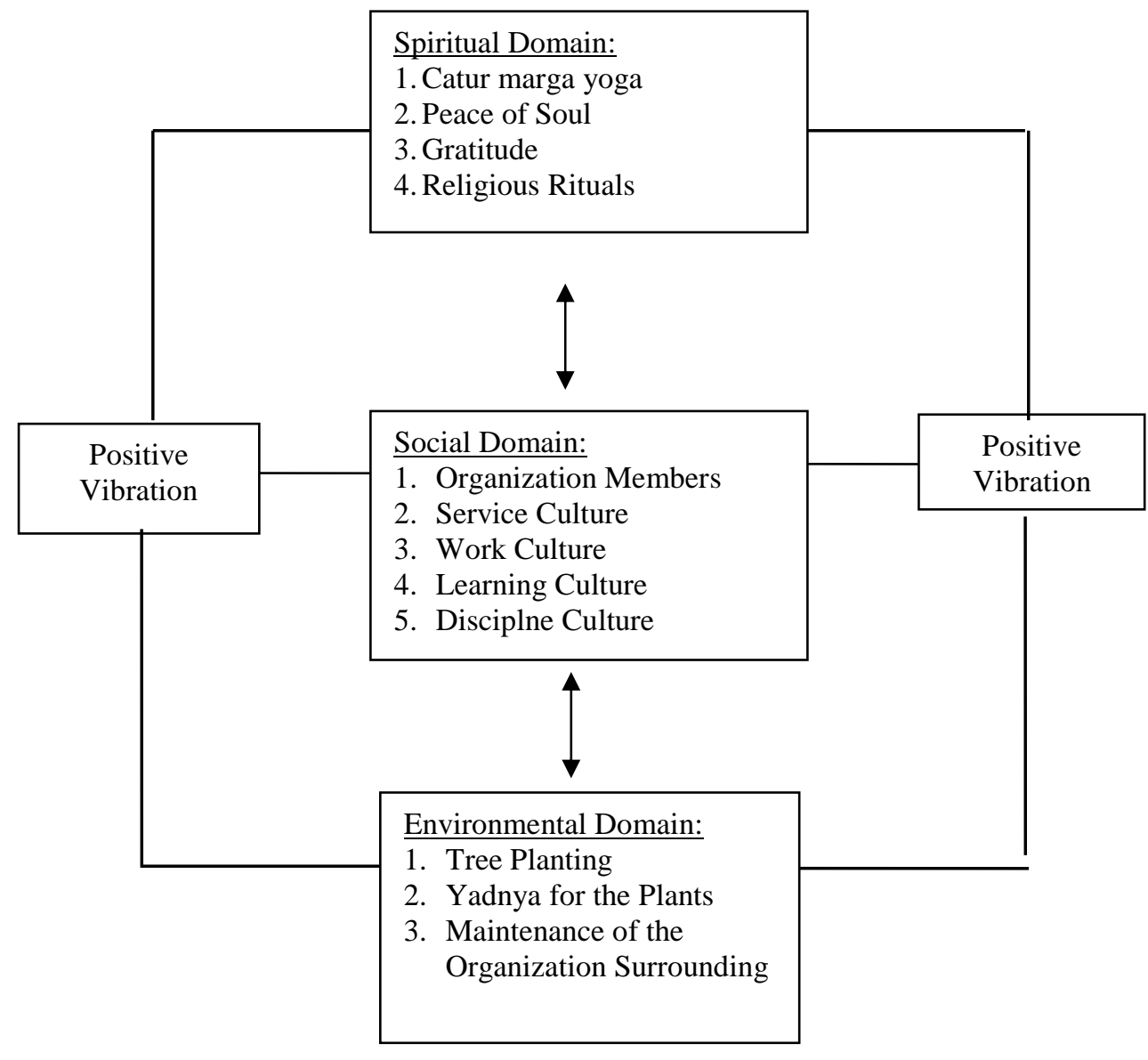

\section{Conclusion}

Based on the above explanation it can be concluded that the Harmonization at Hindu universities conducted in IHDN Denpasar by internalization and socialization of Tri Hita Karana culture aspects are as follows:

1. The harmonious relationship of human beings or members of the organization with God, accomplished through a medium called sacred place called the spiritual domain
2. Harmonious relationship with fellow members of the organization, in the implementation is based on the concept of Hindu religion chess yoga clan and supported the concepts of local wisdom of Bali. Its implementation produces several cultures of serving culture, work culture, learning culture and the discipline culture that we call the term chess culture. The environmental 
activities of members of our organization call the term social domain

3. Harmonious relationship with the environment as a form of respect for plants whose contributions are so great to human life is called the term natural domain. Balance or harmony within the organization can occur if all three aspects can be implemented in an integrated manner supported by the Balinese local wisdom concepts.

\section{References}

Amstrong, M. 2014. Handbook of Human Resource Management (13th Edition). Kogan Page Publisher.

Atallah. 2013. The Impact of Knowledge Management Functions on the Organizational Excellence from the Perspective of the University of AlTaif Staff. nterdiciplinary Journal Of Contemporary Research In Business, 5 (3): 170-192.

Anders D. Olofsson and Ola J. Lindberg.2018. Students' voices about information and communication technology in upper secondary schools. The International Journal of Information and Learning Technology. Vol. 35 No. 2. pp. 82-92 Bogdan, R.C. \& Biklen, S.K. 1998. Qualitative Research for Education: An Intriduction to Theory and Methods. Boston: Allyn and Bacon, Inc.

Creswel, John W. (2009). Research design : Qualitative, quantitative, and mixed methods approaches. Los angeles: University of Nebraska-Lincoln.
Dahliani. (2015). Local wisdom in built environment in globalization era. Journal of Education and Research (on Line) Vol 3. 157-166.

Damayanthi, 2011. Pengungkapan Tanggung Jawab Sosial Lembaga Perkreditan Desa (LPD) Berdasarkan Filosofi Tri Hita Karana, Jurnal Ilmiah Akuntansi \& Bisnis, Vol 6. No. 2.

Djayastra, 2012. Peran Lembaga Perkreditan Desa Dalam

Pemberdayaan EkonomiMasyarakat Desa Adat Berlandaskan Modal Sosial, Disertasi Program Doktor Ilmu Ekonomi Pascasarjana Fakultas Ekonomi dan Bisnis Universitas Brawijaya, Malang. Disertasi tidak dipublikasikan

Eramuri, Karel Marthen.(2016. Tinjauan Konsep Comunity Depelovement artikel web.diakses dari https://id.linkedin.com/pulse/tinjauan -konsep-community-developmentkarel-eramuri, pada tanggal 12-092017

Ezane Joseph, Kodjo\& Changjun Dai.2009. The Influence of Organizational Culture onOrganizational Learning, Worker Involvement and Worker Productivity. Journal International Journal of Business and Management. Vol. 4, No. 9.pp 249250

Gunawan, 2011. Peran Falsafah Tri Hita Karana bagi Pertumbuhan dan Kinerja Lembaga Perkreditan Desa (LPD) di Bali, Jurnal Analisis Manajemen, Vol. 5, No. 2. 
Heregenhahn, B.R. \& Olson, Matthew H. (2014). Theories of learning. Jakarta : Prenadamedia Group

Jarad, Ismail Younis. (2010). A review paper on organizational cultural and organizational performance International Journal of Business and Social Science Vol. 1 No. 3; December 2010. ISSN 2289-8441. Malaysia: University Pahang Malaysia.

Lance. Am, (2010). A case of study of two schools identifying core values conducive to the building of a positive shcool culture. SAGE : Management Education Journal. Vol 24. Issue 3. Page(s) 118-123.

Lewin, Kurt. A dynamic theory of personality. (1935). New York and London : Mc Grow Hill Book Company.

Nirva, Diana. 2012.Manajemen Pendidikan Berbasis Budaya Lokal Lampung (Analisis Eksploratif Mencari Basis Filosofis).Jurnal Analisis . Vol. 12, No.1, 183-208

Selasih, N. N., \& Sudarsana, I. K. (2018). Education Based on Ethnopedagogy in Maintaining and Conserving the Local Wisdom: A Literature Study. Jurnal Ilmiah Peuradeun, 6(2), 293-306.

Sharma, Sagar. (2016). Impact of globalization on mental health in lowand middle - 1 Home Countries.SAGE Jornal: Psychological and Developing Scienties. Vol 28, no 7.

Steward, Julian H. (1990). Theory of culture change, University of Illinois Press.
Sudarsana, I. K. (2017). Interpretation Meaning of Ngaben for Krama Dadia Arya Kubontubuh Tirtha Sari Ulakan Village Karangasem District (Hindu Religious Education Perspective). Vidyottama Sanatana: International Journal of Hindu Science and Religious Studies, 1(1), 1-13.

Sugiharta, I. P. S. O., \& Sudarsana, I. K. (2017). Hypnotic Learning Characteristics On Sisya Brahmakunta Community In Denpasar. Vidyottama Sanatana: International Journal of Hindu Science and Religious Studies, 1(2), 132-145.

Thawinkarn, Dawruwan. (2015). Local wisdom model in school education manajemen.Journal of educational Administration khon Kaen University (Vol.11. No.1).

Ulfatin, Nurul, (2015). Metode penelitian kualitatif di bidang pendidikan: Teori dan Aplikasinya. Malang: Media Nusa Kreatif.

Wijaya, A.A. Prima Surya, 2010. Memahami Catur Marga Empat Jalan Mencapai Tuhan, Surabaya: Penerbit Paramita.

Wibowo. 2010. Manajemen Kinerja. Jakarta: PT. Raja Grafindo Persada.

Windia, W., dan Ratna, K. D. 2007. Analisis Bisnis yang Berlandaskan Tri Hita Karana. Denpasar: Penerbit Universitas Udayana

Windia, W.2013. Subak Warisan Dunia. Denpasar: Udayana University Press. Wirajaya, A. G.2014. The Accountability in the Dimension of TRI HITA Karana (THK). Scientific Research Journal (SCIRJ), Volume II,pp 10-17. 